\title{
DUSZPASTERSKIE TOWARZYSZENIE MAŁŻONKOM W ODPOWIEDZIALNYM RODZICIELSTWIE
}

\author{
PASTORAL ACCOMPANIMENT \\ OF SPOUSES IN RESPONSIBLE PARENTHOOD
}

\begin{abstract}
A b stract. Pastoral accompaniment of spouses in responsible parenthood is one of the important tasks of this salvific activity of the Church. Spouses invited by God to pursue their parental vocation await the support of pastors. This support is realized by priests through the preaching of the word of God, parish family counseling, the ministry of spiritual direction and prayer support, or in the process of pedagogy. Surveys among presbyters have shown that a high percentage of priests declare their willingness to accompany their spouses in the work of responsible parenthood. More often than not, priests from the age of 36 years of age, who have more experience in ministering to married couples, consider it this way. The challenge of pastoral support for spouses in responsible parenthood is faced by younger priests up to 35 years of age.
\end{abstract}

Key words: pastoral accompaniment of married; responsible parenthood; pastoral care of married couples; empirical study of priests.

Sakramenty małżeństwa i kapłaństwa służą komunii kościelnej i zbawieniu wiernych ${ }^{1}$. Małżonkowie służą sobie nawzajem bezinteresownym darem z siebie, którego wyrazem jest wzajemna miłość, owocująca „potrzebą obdarzenia

Ks. mgr lic. Grzegorz CzerwonkA - prezbiter archidiecezji przemyskiej, doktorant w Instytucie Nauk Teologicznych Katolickiego Uniwersytetu Lubelskiego Jana Pawła II; adres do korespondencji: Al. Racławickie 14, 20-950 Lublin; e-mail: grzechczer@gmail.com; ORCID: http://orcid.org/00000001-8783-4443

Rev. Grzegorz Czerwonka - presbyter of the Archdiocese of Przemyśl, Ph.D. student at the Institute of Theological Sciences of the John Paul II Catholic University of Lublin; address for correspondence: Al. Racławickie 14, 20-950 Lublin; e-mail: grzechczer@gmail.com; ORCID: http:/orcid. org/0000-0001-8783-4443

\footnotetext{
${ }^{1}$ KKK 1534.
} 
człowieczeństwem innych istot, którymi w swoim czasie Bóg ich obdarzy"². Kapłaństwo jest całkowitym darem miłości pasterskiej, ofiarowanym Kościołowi ${ }^{3}$, w którym szczególne miejsce zajmują rodziny. Obecna sytuacja małżeństwa i rodziny stanowi wyzwanie dla Kościoła i wymaga odpowiednich działań w obszarze duszpasterstwa rodzin. W obliczu narastającej cywilizacji śmierci, która występuje przeciw życiu oraz powołaniu do rodzicielstwa, opatrznościowy staje się głos Kościoła zawarty w adhortacji Amoris laetitia. Dokument ten wskazuje na potrzebę duszpasterskiego wsparcia rodziny: „Wszystkie działania duszpasterskie zmierzające do pomocy małżonkom, by wzrastali w miłości i przeżywaniu Ewangelii w rodzinie, są bezcenne"4.

Niniejszy artykuł zawiera refleksję teologicznopastoralną nad duszpasterskim towarzyszeniem małżonkom w służbie życiu i realizacji odpowiedzialnego rodzicielstwa. Zostanie w nim podjęta próba odpowiedzi na pytania, w jakim stopniu duszpasterze są gotowi oraz w jaki sposób powinni towarzyszyć małżonkom w odpowiedzialnym rodzicielstwie. Podstawowym źródłem tego opracowania są dokumenty magisterium Kościoła współczesnego, zwłaszcza nauczanie papieży Jana Pawła II i Franciszka, oraz wyniki badań własnych przeprowadzonych w grudniu 2019 roku na próbie 79 prezbiterów archidiecezji przemyskiej.

\section{ODPOWIEDZIALNE RODZICIELSTWO A POTRZEBA WSPARCIA W JEGO REALIZACJI}

W sensie ścisłym odpowiedzialne rodzicielstwo dotyczy „bezpośrednio i wprost tego momentu, w którym mężczyzna i kobieta, łącząc się ze sobą «jako jedno ciało», mogą stać się rodzicami" ‘. Bóg, zwracając się do człowieka: do mężczyzny i kobiety, mówi: „Bądźcie płodni i rozmnażajcie się” (Rdz 1,28). Miłość ze swej natury nie zamyka się w sobie, ale ontologicznie jest otwarta na dawanie. Bóg, który jest Miłością, stwarzając człowieka na swój obraz i podobieństwo, wpisał w ludzką naturę zdolność do miłości płodnej, rodzącej, która pomnaża się, obdarzając nowym

2 Por. JAN PAwel II, „Medytacja o bezinteresownym darze (8.02.1994)”, 2-3, https://opoka.org.pl/ biblioteka/W/WP/jan_pawel_ii/inne/medytacja_08021994.html [dostęp: 30.01.2020].

${ }^{3} J_{\text {AN PAWE }}$ II, Adhortacja apostolska „Pastores dabo vobis” [dostęp: 25.03.1992], 23.

${ }^{4}$ FranciszeK, Adhortacja apostolska „Amoris laetitia” (19.03.2016) (Wrocław: Wydawnictwo Wrocławskiej Księgarni Archidiecezjalnej, 2016), 208 [dalej cyt. AL].

${ }^{5}$ JAN PAWEe II, „List do Rodzin «Gratissimam sane» (2.02.1994)”, w Posoborowe dokumenty Kościoła katolickiego o małżeństwie i rodzinie, t. 2, red. Kazimierz Lubowicki (Kraków: Wydawnictwo M, 1999), 12. 
życiem. Małżonkowie, którzy przez miłość stają się jedno, są więc zaproszeni przez Boga do miłości, która przekracza ich samych oraz jest płodna, czyli otwarta na poczęcie nowego życia ${ }^{6}$. „Płodność jest owocem i znakiem miłości małżeńskiej, żywym świadectwem pełnego wzajemnego oddawania się małżonków"7. Bogactwo płodności małżeńskiej miłości nie ogranicza się do wymiaru fizycznego rodzenia dzieci, ale obejmuje także przekazywanie potomstwu owoców życia moralnego, duchowego i nadprzyrodzonego ${ }^{8}$.

Kościół wychodzi z duszpasterską troską, by nieść wsparcie dla małżonków w dziele odpowiedzialnego rodzicielstwa. Duszpasterstwo rodzin jest działalnością wspólnoty Kościoła, której celem jest urzeczywistnienie się zbawczego planu Chrystusa wobec małżeństwa i rodziny ${ }^{9}$. „Współczesne towarzyszenie rodzinie wymaga wzmożonego zainteresowania i wysiłku Kościoła, pastoralnego nawrócenia i odpowiedniej formacji podmiotów, a także cierpliwości i wytrwałości w ich realizacji”" ${ }^{10}$. Ważnym obszarem duszpasterskiego wsparcia jest niewątpliwie towarzyszenie małżonkom w odpowiedzialnym rodzicielstwie, realizujące się poprzez przepowiadanie słowa Bożego, parafialne poradnictwo rodzinne, posługę kierownictwa duchowego, pedagogizację rodziców oraz modlitewne wsparcie małżonków.

Duszpasterze wezwani do głoszenia małżonkom orędzia Bożego, którego sercem jest Ewangelia życia ${ }^{11}$, odnajdują przestrzeń realizacji swej misji zwłaszcza w przepowiadaniu kaznodziejskim i katechetycznym skierowanym do młodzieży, narzeczonych, małżonków i rodziców. Szczególnie naglące jest w obecnym czasie odważne przepowiadanie o świętości każdego ludzkiego życia oraz powołaniu do służby życiu, do którego zaproszeni są w sposób wyjątkowy małżonkowie. Towarzyszenie duszpasterskie małżonkom w wypełnianiu powołania do odpowiedzialnego rodzicielstwa wymaga również, aby duszpasterze nie pomijali nauczania

\footnotetext{
${ }^{6}$ Por. AL 80; Pawee VI, Encyklika „Humanae vitae” (25.07.1968 r.), 9; Antonio Gerardo FidaLGO, „Rzeczywistość miłości jako fundament małżeństwa i rodziny”, w Amoris laetitia jako ewangelia miłości i droga do przebycia, red. Giovanni del Missier, Antonio Gerardo Fidalgo (Kraków: Wydawnictwo Homo Dei, 2019), 76.

${ }^{7}$ JAN Pawel II, Adhortacja apostolska „Familiaris consortio” (22.11.1981), 28 [dalej cyt. FC]; zob. KKK 2366.

${ }^{8} \mathrm{FC} 28$.

${ }^{9}$ Konferencja EPISKOPATU Polski, Dyrektorium duszpasterstwa rodzin (1.05.2003) (Warszawa: Fundacja Vita Familiae, 2003), 1.

${ }^{10}$ Jacek Goleń, „The Challenges of Accompanying Families in Light of the Apostolic Exhortation Amoris Laetitia”, Rocznik Teologii Katolickiej 17, nr 1 (2018): 104-105; zob. José Granados, Stephan Kampowski i Juan José PÉrez-Soba, Accompanying, Discerning, Integrating. A Handbook for the Pastoral Care of the Family According to Amoris Laetitia (Steubenville: Emmaus Road Publishing, 2015), 13-5.
}

${ }^{11}$ Jan PaWee II, Encyklika ,Evangelium vitae” (25.03.1995), 1 [dalej cyt. EV]. 
moralnego odnoszącego się do życia małżeńskiego, ale poruszali zagadnienia etyki życia małżeńskiego i odpowiedzialnej prokreacji. Wymaga to niewątpliwie właściwego przygotowania intelektualnego duszpasterzy, czyli pogłębienia ich formacji dotyczącej powołania małżeńsko-rodzinnego ${ }^{12}$.

Szczególnym miejscem głoszenia Bożego zamysłu wobec małżeństwa i rodziny oraz towarzyszenia pastoralnego rodzinie jest przygotowanie młodzieży i narzeczonych do sakramentu małżeństwa ${ }^{13}$. Katecheza młodzieży poprzedzająca ten sakrament stanowi ważne miejsce duszpasterskiego wsparcia w przyszłej realizacji powołania do rodzicielstwa. Istotne jest bowiem „takie wychowanie człowieka, aby był zdolny realizować swoją płciowość w służbie miłości, w ramach małżeństwa i rodziny, z otwarciem się na prokreację"14.

Nieocenioną formą duszpasterskiego towarzyszenia małżonkom jest poradnictwo rodzinne. Do celów, jakie sobie ono stawia, należy między innymi pomoc narzeczonym, małżonkom i rodzinom w realizowaniu Bożego zamysłu wobec rodziny, zachowaniu i rozwoju więzi emocjonalnych oraz realizacji odpowiedzialnego rodzicielstwa ${ }^{15}$. W duszpasterskiej rzeczywistości Kościoła polskiego znaczącą rolę spełniają parafialne poradnie rodzinne, których misją jest szczególnie „nauczanie zasad odpowiedzialnego rodzicielstwa, w tym metod rozpoznawania płodności" ${ }^{16}$. Duszpasterze służący małżonkom w poradniach powinni pamiętać, że ich wsparcie służy formacji prawego sumienia małżonków oraz ukazywaniu obowiązków rodzicielskich wobec Boga, wobec siebie samych, rodziny i społeczeństwa ${ }^{17}$. Takie towarzyszenie małżonkom będzie niekiedy wymagało skierowania ich do skorzystania $\mathrm{z}$ fachowej pomocy, jaką oferują specjaliści w zakresie odpowiedzialnego rodzicielstwa.

Duszpasterskie wsparcie rodziców w odpowiedzialnym rodzicielstwie obejmuje również towarzyszenie małżonkom w kierownictwie duchowym. „Kierownik

${ }^{12} \mathrm{FC} 34$.

${ }^{13}$ Jacek Goleń, „Duszpasterstwo rodzin wsparciem rodziców w wychowaniu”, Roczniki Teologiczne 66, z. 6 (2019): 178.

${ }^{14}$ Dorota Kornas-Biela, „Pedagogika prenatalna”, w Pedagogika. Podręcznik akademicki. Subdyscypliny i dziedziny wiedzy o edukacji, t. 4, red. Bogdan Śliwerski (Gdańsk: Gdańskie Wydawnictwo Psychologiczne, 2010), 167.

${ }^{15}$ Jacek GoLEŃ, „Poradnictwo małżeńsko-rodzinne”, w Duszpasterstwo rodzin, Refleksja naukowa i działalność pastoralna, red. Ryszard Kamiński, Grzegorz Pyźlak i Jacek Goleń (Lublin: Wydawnictwo KUL, 2013), 379.

${ }^{16}$ Jacek GoLEN', „Parish Family Counseling Centers”, w Catholic Family Ministry. The Scientific Reflection and the Practical Ministry of the Church, red. Jacek Goleń, Ryszard Kamiński i Grzegorz Pyźlak (Lublin: Wydawnictwo KUL, 2018), 343.

${ }^{17}$ Goleń, „Parish Family”. 
duchowy, wsłuchując się w doświadczenie Boga u małżonków oraz rozeznając ich pragnienia rodzicielskie, pomaga usłyszeć wezwanie Boże do płodnej miłości"18. Istotnym obszarem kierownictwa duchowego małżonków jest również towarzyszenie realizacji płodności duchowej, realizującej się w wychowaniu potomstwa oraz przekazie wiary. Ponadto kierownictwo duchowe może stać się okazją do odkrywania przez małżonków bezdzietnych, przeżywających, że płodność jako dar Boży ma również swój wymiar duchowy - w postaci duchowego rodzicielstwa. Wówczas nieocenioną wartość ma duszpasterskie wsparcie małżonków w ich indywidualnym i małżeńskim rozwoju duchowym ${ }^{19}$. Kierownik duchowy może także zachęcić małżonków do leczenia niepłodności, zgodnego z normami etycznymi, a w razie potrzeby wyjaśnić kwestie etyczne sztucznych zapłodnień i powody ich moralnej niedopuszczalności. Cenną pomocą wydaje się rozeznawanie z małżonkami wezwania Bożego do podjęcia przez nich adopcji lub też głębszego zaangażowania we wspólnotę Kościoła, zwłaszcza w troskę o ludzkie życie ${ }^{20}$.

Odpowiedzialność rodzicielska, jako służba życiu, wiąże się nieodłącznie również z wychowaniem dzieci. Rodzina stanowi najważniejsze dla człowieka środowisko wychowawcze. „Zadaniem Kościoła jest kształtowanie pozytywnego stosunku rodziców do swego powołania rodzicielskiego oraz pomoc w jego realizacji. Działalność ewangelizacyjna i duszpasterska Kościoła mobilizuje rodziców do własnej pracy formacyjnej i kształtowania osobowości oraz pełnienia ról ojca i matki”21. Duszpasterze towarzyszący rodzicom w dziele wychowania mogą wspomóc ich poprzez misję edukacyjną, którą określa się mianem pedagogizacji. Jej głównym zadaniem jest budzenie u rodziców postawy wytrwałego poszukiwania i celowego zmagania o polepszenie sytuacji rodzinnej w zakresie wychowania dziecka ${ }^{22}$. Realizacja tej misji może opierać się na inicjowaniu spotkań formacyjnych dla rodziców dotyczących zadań wychowawczych, zwłaszcza spotkań ze specjalistami, którzy

${ }^{18}$ Jacek Goleń, „Spiritual Direction for Spouses”, w Catholic Family Ministry. The Scientific Reflection and the Practical Ministry of the Church, red. Jacek Goleń, Ryszard Kamiński i Grzegorz Pyźlak (Lublin: Wydawnictwo KUL, 2018), 296.

${ }^{19}$ GoLEŃ, „Spiritual Direction”, 297-8.

${ }^{20}$ Tamże.

${ }^{21}$ Jacek GoLEŃ, „Wspieranie rodzin w wychowaniu seksualnym”, w Towarzyszyć matżeństwu i rodzinie. Inspiracje adhortacji apostolskie Amoris laetitia dla duszpasterstwa rodzin, red. Jacek GoLEŃ (Lublin: Wydawnictwo KUL, 2017), 351; por. Richard KUCHARČIK, „Odnowa przygotowania do małżeństwa w parafii”, w Duszpasterstwo rodzin w parafii, red. Jacek Goleń i Dariusz Lipiec (Lublin: Wydawnictwo KUL, 2016), 202-3.

${ }^{22}$ Adam Skreczko, „Pedagogizacja rodziców”, w Duszpasterstwo rodzin. Refleksja naukowa i działalność pastoralna, red. Ryszard Kamiński, Grzegorz Pyźlak i Jacek Goleń (Lublin: Wydawnictwo KUL, 2013), 472. 
mogliby wspomóc rodziców w procesie wychowania. Duszpasterskim wsparciem rodziców wychowujących swe dzieci mogą być również nauki rekolekcyjne do nich skierowane, katecheza sakramentalna w związku z przygotowaniem do przyjęcia sakramentów wtajemniczenia chrześcijańskiego przez dzieci czy podejmowanie z rodzicami rozmów duszpasterskich, wynikających z troski o wychowanie ich potomstwa.

Przede wszystkim jednak nie można zapomnieć o istotnej roli wsparcia modlitewnego, którym duszpasterze powinni otaczać małżonków, będących współpracownikami Boga w dziele przekazywania życia. Odpowiedzialność, jaka spoczywa na rodzicach, wymaga przede wszystkim wsparcia łaski Bożej, którą - oprócz ich samych - zwłaszcza osoby duchowne i konsekrowane powinny wypraszać dla małżonków ${ }^{23}$.

\section{BADANA GRUPA ORAZ PRZEBIEG BADAŃ}

Grupę badaną stanowili duszpasterze archidiecezji przemyskiej - 79 prezbiterów. W zastosowanym kwestionariuszu wyróżniono dwa przedziały wiekowe. Pierwszy z nich stanowiło 56 prezbiterów w wieku do 35 lat (70,9\%), a drugi - 23 duchownych w wieku 36 lat i więcej $(29,1 \%)$. Pod względem stażu kapłańskiego również wyróżniono dwa przedziały: do 10 roku kapłaństwa (57 osób; 72,2\%) oraz powyżej 10 roku (22 osoby; $27,8 \%$ ).

Respondentów scharakteryzowano także w zakresie liczby posiadanego rodzeństwa. Spośród wszystkich badanych prezbiterów $12,7 \%$ nie miało rodzeństwa (10 osób), 21,5\% miało jednego brata lub siostrę (17 osób), 36,7\% miało dwoje rodzeństwa ( 29 osób), a troje i więcej rodzeństwa - 29,1\% badanych ( 23 osoby).

Dodatkową formację pastoralną odbyło 54,4\% prezbiterów (43 osoby). Część z nich miała za sobą jeden rodzaj dodatkowej formacji; 16 prezbiterów wskazało na swoją formację w zrzeszeniach kościelnych (ruchy, wspólnoty, stowarzyszenia); 10 określiło, że odbywają studia licencjackie z teologii pastoralnej, a dwóch potwierdziło podjęcie dodatkowej formacji pastoralnej, ale nie określiło jej rodzaju. Ponadto czterech duchownych odbyło formację ewangelizacyjną, a jeden - formację dla kierowników duchowych. Dwa rodzaje dodatkowej formacji wskazało: trzech duchownych, którzy formowali się w zrzeszeniach kościelnych oraz odbyli formację ewangelizacyjną; dwóch duchownych, którzy formację w zrzeszeniach kościelnych łączyli z formacją kierowników duchowych lub spowiedników albo

${ }^{23} \mathrm{EV} 43$. 
studiami licencjackimi z teologii pastoralnej. Trzy rodzaje dodatkowej formacji wskazało czterech respondentów. Formację w zrzeszeniach kościelnych łączyli oni z: formacjami ewangelizacyjną oraz dla kierowników duchowych (dwie osoby), ewangelizacyjną oraz dla spowiedników (jedna osoba), formacjami dla spowiedników i dla kierowników duchowych (jedna osoba). Ponadto jedna osoba zadeklarowała cztery rodzaje odbytej formacji dodatkowej: w zrzeszeniach kościelnych, do posługi spowiadania, kierownictwa duchowego oraz ewangelizacyjną. Badania przemyskich duszpasterzy przeprowadzono w grudniu 2019 r., za pomocą autorskiego kwestionariusza ankiety; 28 osób zostało przebadanych osobiście przez autora metodą audytoryjną, natomiast pozostałe kwestionariusze rozesłano drogą internetową z wykorzystaniem narzędzia Formularze Googla ${ }^{24}$.

Wykorzystując standardowe metody analizy opisowej i statystycznej, wyniki zaprezentowano jako: częstość odpowiedzi (\% grupy) oraz wielkość grup udzielających odpowiedzi ( $n$ z całości grupy badanej). Ze względu na zastosowanie skali odpowiedzi - od 0 do 5 - do oceny wyników wykorzystano również średnią arytmetyczną $(M)$, medianę $(M e)$ oraz odchylenie standardowe $(S D)$. Do analizy wyników użyto m.in. testu Shapiro-Wilka, który pozwala ocenić zgodność rozkładu w przypadku rozkładu normalnego. Zmienne nie mające rozkładu zbliżonego do normalnego przeanalizowano między grupami testem Manna-Whitneya (odpowiedni test t Studenta - do porównań dwóch grup) oraz testem Kruskala-Wallisa (odpowiednik testu ANOVA - do porównań trzech lub większej liczby grup). Uzyskane różnice dla wartości ze statystyk opisowych uznawano za istotne, gdy wartość $p<0,05$ $\mathrm{z}$ testów statystycznych.

\section{GOTOWOŚĆ DUSZPASTERZY DO TOWARZYSZENIA MAŁŻONKOM}

W przeprowadzonych badaniach uwzględniono poczucie gotowości duszpasterzy do towarzyszenia małżonkom w odpowiedzialnym rodzicielstwie. Wyniki zaprezentowane w tabeli 1 wskazują, że badani na ogół zgadzają się z twierdzeniem dotyczącym gotowości przepowiadania o świętości i nienaruszalności ludzkiego życia (75,9\%). Wysoki odsetek duszpasterzy deklaruje gotowość podjęcia modlitwy wspierającej małżonków w ich misji prokreacyjno-wychowawczej $(63,3 \%)$, objaśniania kwestii dotyczących grzechów małżeńskich (aborcja, antykoncepcja,

\footnotetext{
${ }^{24}$ https://docs.google.com/forms/d/e/1FAIpQLSePABAuvNLVqiGbNsHvsaJnrrqvudUeuMjY_RYoNw8f1 VC9qA/viewform?usp=sf_link [dostęp: 13.12.2019].
} 
zapłodnienie in vitro) (60,8\%), ukazywania małżonkom ich powołania jako służby życiu powierzonej przez Boga (58,2\%) oraz przekazywania nauczania moralnego Kościoła odnoszącego się do odpowiedzialnego rodzicielstwa (50,6\%). Ponadto znaczny odsetek respondentów deklaruje, że odczuwa gotowość zachęcania małżonków do poznawania i kierowania się naturalnymi rytmami płodności oraz do korzystania z NaProTECHNOLOGY (43\%), prowadzenia spotkań formacyjnych dla rodziców w ramach przygotowania do Pierwszej Komunii Świętej i sakramentu bierzmowania $(39,2 \%)$, prowadzenia rozmów z rodzicami na temat wychowania dzieci $(41,8 \%)$, wspierania małżonków przeżywających problem niepłodności (39,2\%), przepowiadania ( $w$ formie kazań i katechez) odnośnie do etyki małżeńskiej i odpowiedzialnego rodzicielstwa $(35,4 \%)$, a także pogłębiania swoich kompetencji, aby lepiej pomagać małżonkom w ich misji odpowiedzialnej prokreacji $(35,4 \%)$.

Badani duszpasterze w dużym stopniu zgadzają się z twierdzeniami dotyczącymi: prowadzenia rozmów z rodzicami na temat wychowania dzieci (41,8\%), pogłębiania swoich kompetencji, aby lepiej pomagać małżonkom w ich misji odpowiedzialnej prokreacji $(39,2 \%)$, prowadzenia spotkań formacyjnych dla rodziców w ramach przygotowania do Pierwszej Komunii Świętej i sakramentu bierzmowania $(39,2 \%)$, przepowiadania (w formie kazań i katechez) odnośnie do etyki małżeńskiej i odpowiedzialnego rodzicielstwa (34,2\%).

Interesujące wydaje się to, iż niewielki odsetek badanych duszpasterzy zupełnie lub w dużym stopniu nie odczuwa gotowości do niesienia wsparcia małżonkom w odpowiedzialnym rodzicielstwie poprzez przepowiadanie na temat etyki małżeńskiej i odpowiedzialnego rodzicielstwa oraz poprzez zachęcanie małżonków do poznawania i kierowania się naturalnymi rytmami płodności, a także do korzystania z NaProTECHNOLOGY (po 3,8\%), poprzez wspieranie małżonków przeżywających problem niepłodności oraz poprzez organizowanie formacji rodziców wspierającej ich w wychowaniu dzieci (po 2,6\%). Nie odczuwają oni także gotowości do wspierania małżonków poprzez pogłębianie swoich kompetencji, aby lepiej pomagać małżonkom w ich misji odpowiedzialnej prokreacji, oraz poprzez modlitwę w intencji małżonków, aby wesprzeć ich w misji prokreacyjno-wychowawczej (po 1,3\%). Wyniki te wskazują na istnienie kilkuprocentowego odsetka duszpasterzy, którzy nie czują się gotowi do towarzyszenia małżonkom w odpowiedzialnym rodzicielstwie.

Przeprowadzona ocena statystyki opisowej ukazuje, że najniższe średnie wyniki wykazano dla pytania 1 i 8 (średnie wyniki wynoszą odpowiednio 3,95\% oraz $3,73 \%$ ), w pozostałych przypadkach wyniki są wyższe od 4,0\%. Średnia korelacja wyników poszczególnych pytań względem siebie wynosi $R_{\text {sr }}=0,373$, a dla testu $\alpha$ Cronbacha $-\alpha=0,871$, co oznacza dobre dopasowanie pytań względem siebie.

Wyniki prezentuje tabela 1 . 
Tabela 1. Liczbowy i procentowy rozkład poczucia gotowości respondentów do duszpasterskiego towarzyszenia małżonkom w odpowiedzialnym rodzicielstwie

\begin{tabular}{|c|c|c|c|c|c|c|c|c|c|c|c|c|c|c|}
\hline \multirow[t]{2}{*}{ Odczuwam gotowość } & \multicolumn{2}{|c|}{$\begin{array}{l}\text { Zupełnie się } \\
\text { nie zgadzam }\end{array}$} & \multicolumn{2}{|c|}{$\begin{array}{c}\text { Nie zgadzam } \\
\text { się w dużym } \\
\text { stopniu }\end{array}$} & \multicolumn{2}{|c|}{$\begin{array}{c}\text { Raczej się } \\
\text { nie zgadzam }\end{array}$} & \multicolumn{2}{|c|}{$\begin{array}{c}\text { Raczej } \\
\text { się zgadzam }\end{array}$} & \multicolumn{2}{|c|}{$\begin{array}{c}\text { W dużym } \\
\text { stopniu } \\
\text { się zgadzam }\end{array}$} & \multicolumn{2}{|c|}{$\begin{array}{l}\text { W pełni się } \\
\text { zgadzam }\end{array}$} & \multirow[t]{2}{*}{$M$} & \multirow[t]{2}{*}{$S D$} \\
\hline & $N$ & $\%$ & $N$ & $\%$ & $N$ & $\%$ & $N$ & $\%$ & $N$ & $\%$ & $N$ & $\%$ & & \\
\hline $\begin{array}{l}\text { 1. Przepowiadania (w formie } \\
\text { kazań i katechez) na temat etyki } \\
\text { małżeńskiej i odpowiedzialnego } \\
\text { rodzicielstwa }\end{array}$ & 1 & $1,3 \%$ & 2 & $2,5 \%$ & 1 & $1,3 \%$ & 20 & $25,3 \%$ & 27 & $34,2 \%$ & 28 & $35,4 \%$ & 3,95 & 1,05 \\
\hline $\begin{array}{l}\text { 2. Przepowiadania o świętości } \\
\text { i nienaruszalności ludzkiego } \\
\text { życia }\end{array}$ & 0 & $0,0 \%$ & 0 & $0,0 \%$ & 0 & $0,0 \%$ & 3 & $3,8 \%$ & 16 & $20,3 \%$ & 60 & $75,9 \%$ & 4,72 & 0,53 \\
\hline $\begin{array}{l}\text { 3. Ukazywania małżonkom ich } \\
\text { powołania jako służby życiu } \\
\text { powierzonej przez Boga }\end{array}$ & 0 & $0,0 \%$ & 0 & $0,0 \%$ & 0 & $0,0 \%$ & 8 & $10,1 \%$ & 25 & $31,6 \%$ & 46 & $58,2 \%$ & 4,48 & 0,68 \\
\hline $\begin{array}{l}\text { 4. Pogłębiania moich } \\
\text { kompetencji, aby lepiej } \\
\text { pomagać małżonkom w ich } \\
\text { misji odpowiedzialnej } \\
\text { prokreacji }\end{array}$ & 1 & $1,3 \%$ & 0 & $0,0 \%$ & 3 & $3,8 \%$ & 16 & $20,3 \%$ & 31 & $39,2 \%$ & 28 & $35,4 \%$ & 4,03 & 0,96 \\
\hline $\begin{array}{l}\text { 5. Objaśniania, na czym } \\
\text { polegają grzechy popełniane } \\
\text { przez małżonków (aborcja, } \\
\text { antykoncepcja, zapłodnienie } \\
\text { in vitro) }\end{array}$ & 0 & $0,0 \%$ & 0 & $0,0 \%$ & 3 & $3,8 \%$ & 11 & $13,9 \%$ & 17 & $21,5 \%$ & 48 & $60,8 \%$ & 4,39 & 0,87 \\
\hline $\begin{array}{l}\text { 6. Prowadzenia spotkań } \\
\text { formacyjnych dla rodziców } \\
\text { w ramach przygotowania do } \\
\text { I Komunii św. i sakramentu } \\
\text { bierzmowania }\end{array}$ & 0 & $0,0 \%$ & 0 & $0,0 \%$ & 0 & $0,0 \%$ & 17 & $21,5 \%$ & 31 & $39,2 \%$ & 31 & $39,2 \%$ & 4,18 & 0,76 \\
\hline $\begin{array}{l}\text { 7. Wspierania małżonków } \\
\text { przeżywających problem } \\
\text { niepłodności }\end{array}$ & 1 & $1,3 \%$ & 1 & $1,3 \%$ & 3 & $3,8 \%$ & 18 & $22,8 \%$ & 25 & $31,6 \%$ & 31 & $39,2 \%$ & 4,00 & 1,05 \\
\hline $\begin{array}{l}\text { 8. Organizowania formacji } \\
\text { rodziców wspierającej ich } \\
\text { w wychowaniu dzieci }\end{array}$ & 1 & $1,3 \%$ & 1 & $1,3 \%$ & 4 & $5,1 \%$ & 27 & $34,2 \%$ & 25 & $31,6 \%$ & 21 & $26,6 \%$ & 3,73 & 1,03 \\
\hline $\begin{array}{l}\text { 9. Przekazywania nauczania } \\
\text { moralnego Kościoła } \\
\text { dotyczącego odpowiedzialnego } \\
\text { rodzicielstwa }\end{array}$ & 0 & $0,0 \%$ & 0 & $0,0 \%$ & 3 & $3,8 \%$ & 12 & $15,2 \%$ & 24 & $30,4 \%$ & 40 & $50,6 \%$ & 4,28 & 0,86 \\
\hline $\begin{array}{l}\text { 10. Zachęcania małżonków } \\
\text { do poznawania i kierowania } \\
\text { się naturalnymi rytmami } \\
\text { płodności oraz do korzystania } \\
\text { z NaProTECHNOLOGY }\end{array}$ & 1 & $1,3 \%$ & 2 & $2,5 \%$ & 4 & $5,1 \%$ & 14 & $17,7 \%$ & 24 & $30,4 \%$ & 34 & $43,0 \%$ & 4,03 & 1,12 \\
\hline $\begin{array}{l}\text { 11. Modlitwy w intencji } \\
\text { małżonków, aby wesprzeć ich } \\
\text { w ich misji prokreacyjno- } \\
\text {-wychowawczej }\end{array}$ & 0 & $0,0 \%$ & 1 & $1,3 \%$ & 1 & $1,3 \%$ & 5 & $6,3 \%$ & 22 & $27,8 \%$ & 50 & $63,3 \%$ & 4,51 & 0,78 \\
\hline $\begin{array}{l}\text { 12. Prowadzenia rozmów } \\
\text { z rodzicami dotyczących } \\
\text { wychowania dzieci }\end{array}$ & 0 & $0,0 \%$ & 0 & $0,0 \%$ & 3 & $3,8 \%$ & 10 & $12,7 \%$ & 33 & $41,8 \%$ & 33 & $41,8 \%$ & 4,22 & 0,81 \\
\hline
\end{tabular}

Oznaczenia: $N$ - wielkość grup udzielających odpowiedzi, $M$ - średnia, $S D$ - odchylenie standardowe.

W analizie statystycznej uwzględniono wpływ zmiennych niezależnych, takich jak wiek prezbiterów, staż kapłański, odbycie jako prezbiter dodatkowej formacji pastoralnej, na poczucie gotowości duszpasterzy do towarzyszenia małżonkom w odpowiedzialnym rodzicielstwie. 
Wyniki zaprezentowane w tabeli 2 wskazują, że jedynie w trzech przypadkach spośród 12 występują istotne statycznie różnice między duszpasterzami ze względu na wiek. Wykazano statystycznie istotną różnicę w zakresie twierdzenia dotyczącego pogłębiania kompetencji dla efektywniejszej pomocy małżonkom w ich misji odpowiedzialnej prokreacji ( $p=0,038$; różnica średnich 0,45 punktu). Wynika z niego, że duchowni powyżej 36 roku życia odczuwają większą potrzebę rozwijania swoich kompetencji w zakresie wsparcia małżonków w odpowiedzialnym rodzicielstwie $(M=4,35 \pm 0,83)$ niż kapłani młodsi $(M=3,89 \pm 0,98)$.

Ponadto kapłani powyżej 36 roku życia stosunkowo w większym stopniu są gotowi do wspierania małżonków przeżywających problem niepłodności $(p=0,015$, różnica średnich 0,55 punktu). Starsi duchowni $(M=4,39 \pm 0,72)$ zadeklarowali stosunkowo w większym stopniu przekonanie do tej formy wsparcia małżonków niż kapłani młodsi ( $M=$ $3,84 \pm 1,12$ ). Prezbiterzy w wieku od 36 roku życia w większym stopniu niż kapłani do 35 roku życia są gotowi do organizowania formacji rodziców wspierającej ich w wychowaniu dzieci ( $p=0,041$, różnica średnich 0,62 punktu). Duszpasterze starsi $(M=4,17 \pm$ $\pm 0,78)$ są bardziej przekonani do pedagogizacji rodziców niż młodsi $(M=3,55 \pm 1,08)$.

Tabela 2. Poczucie gotowości do towarzyszenia małżonkom w odpowiedzialnym rodzicielstwie a wiek respondentów

\begin{tabular}{|c|c|c|c|c|c|c|}
\hline \multirow{3}{*}{ Odczuwam gotowość } & \multicolumn{4}{|c|}{ Wiek respondentów } & \multirow{3}{*}{$d M$} & \multirow{3}{*}{$\mathrm{Z}$} \\
\hline & \multicolumn{2}{|c|}{ Do 35 lat } & \multicolumn{2}{|c|}{ Powyżej 36 lat } & & \\
\hline & $M$ & $S D$ & $M$ & $S D$ & & \\
\hline $\begin{array}{l}\text { 1. Przepowiadania (w formie kazań i katechez) na temat etyki } \\
\text { małżeńskiej i odpowiedzialnego rodzicielstwa }\end{array}$ & 3,88 & 1,06 & 4,13 & 1,01 & 0,26 & $-1,229$ \\
\hline $\begin{array}{l}\text { 2. Przepowiadania o świętości i nienaruszalności ludzkiego } \\
\text { życia }\end{array}$ & 4,70 & 0,57 & 4,78 & 0,42 & 0,09 & $-0,406$ \\
\hline $\begin{array}{l}\text { 3. Ukazywania małżonkom ich powołania jako służby życiu } \\
\text { powierzonej przez Boga }\end{array}$ & 4,45 & 0,69 & 4,57 & 0,66 & 0,12 & $-0,763$ \\
\hline $\begin{array}{l}\text { 4. Pogłębiania moich kompetencji, aby lepiej pomagać } \\
\text { małżonkom w ich misji odpowiedzialnej prokreacji }\end{array}$ & 3,89 & 0,98 & 4,35 & $\mathbf{0 , 8 3}$ & 0,45 & $-2,080$ \\
\hline $\begin{array}{l}\text { 5. Objaśniania, na czym polegają grzechy popełniane przez } \\
\text { małżonków (aborcja, antykoncepcja, zapłodnienie in vitro) }\end{array}$ & 4,34 & 0,92 & 4,52 & 0,73 & 0,18 & $-0,667$ \\
\hline $\begin{array}{l}\text { 6. Prowadzenia spotkań formacyjnych dla rodziców w ramach } \\
\text { przygotowania do I Komunii św. i sakramentu bierzmowania }\end{array}$ & 4,13 & 0,76 & 4,30 & 0,76 & 0,18 & $-0,966$ \\
\hline $\begin{array}{l}\text { 7. Wspierania małżonków przeżywających problem } \\
\text { niepłodności }\end{array}$ & 3,84 & 1,12 & 4,39 & 0,72 & $\mathbf{0 , 5 5}$ & $-2,041$ \\
\hline $\begin{array}{l}\text { 8. Organizowania formacji rodziców wspierającej ich } \\
\text { w wychowaniu dzieci }\end{array}$ & 3,55 & 1,08 & 4,17 & 0,78 & 0,62 & $-2,427$ \\
\hline $\begin{array}{l}\text { 9. Przekazywania nauczania moralnego Kościoła dotyczącego } \\
\text { odpowiedzialnego rodzicielstwa }\end{array}$ & 4,23 & 0,89 & 4,39 & 0,78 & 0,16 & $-0,660$ \\
\hline $\begin{array}{l}\text { 10. Zachęcania małżonków do poznawania i kierowania } \\
\text { się naturalnymi rytmami płodności oraz do korzystania } \\
\text { z NaProTECHNOLOGY }\end{array}$ & 4,07 & 1,16 & 3,91 & 1,04 & $-0,16$ & 0,882 \\
\hline $\begin{array}{l}\text { 11. Modlitwy w intencji małżonków, aby wesprzeć ich w ich } \\
\text { misji prokreacyjno-wychowawczej }\end{array}$ & 4,46 & 0,85 & 4,61 & 0,58 & 0,14 & $-0,399$ \\
\hline $\begin{array}{l}\text { 12. Prowadzenia rozmów z rodzicami dotyczących } \\
\text { wychowania dzieci }\end{array}$ & 4,18 & 0,86 & 4,30 & 0,70 & 0,13 & $-0,409$ \\
\hline
\end{tabular}

Oznaczenia: $M$ - średnia, $S D$ - odchylenie standardowe; $d M$ - różnice między średnimi, $Z$ - wynik testu Manna-Whitneya, $p$ - poziom istotności. Pogrubionym pismem oznaczono różnice istotne statystycznie. 
Z tabeli 3, prezentującej analizę statystyczną wyników dotyczących gotowości duszpasterzy do towarzyszenia małżonkom względem ich stażu kapłańskiego, wynika, że duchowni powyżej 11. roku kapłaństwa nieco częściej $(M=4,36 \pm 0,73)$ niż młodsi $(M=3,86 \pm 1,13)$ są gotowi wspierać małżonków przeżywających problem niepłodności ( $p=0,073$; różnica średnich 0,50 punktu).

Tabela 3. Poczucie gotowości do towarzyszenia małżonkom w odpowiedzialnym rodzicielstwie a staż kapłański

\begin{tabular}{|c|c|c|c|c|c|c|}
\hline \multirow{3}{*}{ Odczuwam gotowość } & \multicolumn{4}{|c|}{ Staż kapłański } & \multirow{3}{*}{$d M$} & \multirow{3}{*}{$\mathrm{Z}$} \\
\hline & \multicolumn{2}{|c|}{ 1-10 lat } & \multicolumn{2}{|c|}{11 lat i więcej } & & \\
\hline & $M$ & $S D$ & $M$ & $S D$ & & \\
\hline $\begin{array}{l}\text { 1. Przepowiadania (w formie kazań i katechez) na temat etyki } \\
\text { małżeńskiej i odpowiedzialnego rodzicielstwa }\end{array}$ & 3,89 & 1,06 & 4,09 & 1,02 & 0,20 & 0,951 \\
\hline $\begin{array}{l}\text { 2. Przepowiadania o świętości i nienaruszalności ludzkiego } \\
\text { życia }\end{array}$ & 4,70 & 0,57 & 4,77 & 0,43 & 0,07 & 0,272 \\
\hline $\begin{array}{l}\text { 3. Ukazywania małżonkom ich powołania jako służby życiu } \\
\text { powierzonej przez Boga }\end{array}$ & 4,47 & 0,68 & 4,50 & 0,67 & 0,03 & 0,125 \\
\hline $\begin{array}{l}\text { 4. Pogłębiania moich kompetencji, aby lepiej pomagać } \\
\text { małżonkom w ich misji odpowiedzialnej prokreacji }\end{array}$ & 3,93 & 1,00 & 4,27 & 0,83 & 0,34 & 1,469 \\
\hline $\begin{array}{l}\text { 5. Objaśniania, na czym polegają grzechy popełniane przez } \\
\text { małżonków (aborcja, antykoncepcja, zapłodnienie in vitro) }\end{array}$ & 4,37 & 0,92 & 4,45 & 0,74 & 0,09 & 0,075 \\
\hline $\begin{array}{l}\text { 6. Prowadzenia spotkań formacyjnych dla rodziców w ramach } \\
\text { przygotowania do I Komunii św. i sakramentu bierzmowania }\end{array}$ & 4,18 & 0,76 & 4,18 & 0,80 & 0,01 & 0,053 \\
\hline $\begin{array}{l}\text { 7. Wspierania małżonków przeżywających problem } \\
\text { niepłodności }\end{array}$ & 3,86 & 1,13 & 4,36 & 0,73 & $\mathbf{0 , 5 0}$ & 1,791 \\
\hline $\begin{array}{l}\text { 8. Organizowania formacji rodziców wspierającej ich } \\
\text { w wychowaniu dzieci }\end{array}$ & 3,61 & 1,10 & 4,05 & 0,79 & 0,43 & 1,565 \\
\hline $\begin{array}{l}\text { 9. Przekazywania nauczania moralnego Kościoła dotyczącego } \\
\text { odpowiedzialnego rodzicielstwa }\end{array}$ & 4,26 & 0,90 & 4,32 & 0,78 & 0,06 & 0,054 \\
\hline $\begin{array}{l}\text { 10. Zachęcania małżonków do poznawania i kierowania } \\
\text { się naturalnymi rytmami płodności oraz do korzystania } \\
\text { z NaProTECHNOLOGY }\end{array}$ & 4,02 & 1,17 & 4,05 & 1,00 & 0,03 & $-0,157$ \\
\hline $\begin{array}{l}\text { 11. Modlitwy w intencji małżonków, aby wesprzeć ich w ich } \\
\text { misji prokreacyjno-wychowawczej }\end{array}$ & 4,47 & 0,85 & 4,59 & 0,59 & 0,12 & 0,218 \\
\hline $\begin{array}{l}\text { 12. Prowadzenia rozmów z rodzicami, dotyczące wychowania } \\
\text { dzieci }\end{array}$ & 4,19 & 0,85 & 4,27 & 0,70 & 0,08 & 0,142 \\
\hline
\end{tabular}

Oznaczenia: $M$ - średnia, $S D$ - odchylenie standardowe; $d M$ - różnice między średnimi, $Z$ - Wynik testu Manna-Whitneya, $p$ - poziom istotności. Pogrubionym pismem oznaczono różnice istotne statystycznie.

Wyniki umieszczone w tabeli 4, prezentującej analizę statystyczną z uwzględnieniem zmiennej niezależnej liczby posiadanego rodzeństwa, wskazują na występowanie jednej tendencji istotności statystycznej. Posiadanie rodzeństwa pozytywnie wpływa na gotowość organizowania formacji rodziców wspierającej ich w wychowaniu dzieci (nie ma rodzeństwa: $M=3,20 \pm 0,422$; jedno z rodzeństwa: $M=3,47 \pm$ $\pm 1,281$; dwoje rodzeństwa: $M=3,86 \pm 1,060$; troje i więcej rodzeństwa: $M=4,00 \pm$ $\pm 0,905)$. Im więcej rodzeństwa ktoś ma, tym wyższy jest ten wynik $(p=0,062$; różnica średnich 0,80 punktu). 
Tabela 4. Poczucie gotowości do towarzyszenia małżonkom w odpowiedzialnym rodzicielstwie a liczba rodzeństwa respondentów

\begin{tabular}{|c|c|c|c|c|c|c|c|c|c|c|}
\hline \multirow{3}{*}{ Odczuwam gotowość } & \multicolumn{8}{|c|}{ Liczba rodzeństwa respondentów } & \multirow{3}{*}{$d M$} & \multirow{3}{*}{$H$} \\
\hline & \multicolumn{2}{|c|}{ Nie ma rodzeństwa } & \multicolumn{2}{|c|}{$\begin{array}{c}\text { Jedno } \\
\text { z rodzeństwa } \\
\end{array}$} & \multicolumn{2}{|c|}{$\begin{array}{c}\text { Dwoje } \\
\text { z rodzeństwa }\end{array}$} & \multicolumn{2}{|c|}{$\begin{array}{c}\text { Troje } \\
\text { i więcej rodzeństwa }\end{array}$} & & \\
\hline & $M$ & $S D$ & $M$ & $S D$ & $M$ & $S D$ & $M$ & $S D$ & & \\
\hline \begin{tabular}{|l|} 
1. Przepowiadania \\
(w formie kazań i katechez) \\
na temat etyki małżeńskiej \\
i odpowiedzialnego \\
rodzicielstwa
\end{tabular} & 4,10 & 0,876 & 3,88 & 0,857 & 4,03 & 1,210 & 3,83 & 1,072 & 0,27 & 1,728 \\
\hline \begin{tabular}{|l|} 
2. Przepowiadania \\
o świętości \\
i nienaruszalności \\
ludzkiego życia
\end{tabular} & 4,70 & 0,483 & 4,59 & 0,507 & 4,86 & 0,351 & 4,65 & 0,714 & 0,27 & 4,131 \\
\hline $\begin{array}{l}\text { 3. Ukazywania małżonkom } \\
\text { ich powołania jako służby } \\
\text { życiu powierzonej przez } \\
\text { Boga }\end{array}$ & 4,60 & 0,516 & 4,29 & 0,849 & 4,62 & 0,622 & 4,39 & 0,656 & 0,33 & 2,859 \\
\hline $\begin{array}{l}\text { 4. Pogłębiania moich } \\
\text { kompetencji, aby lepiej } \\
\text { pomagać małżonkom w ich } \\
\text { misji odpowiedzialnej } \\
\text { prokreacji }\end{array}$ & 3,80 & 0,632 & 3,94 & 0,899 & 4,07 & 1,100 & 4,13 & 0,968 & 0,33 & 2,369 \\
\hline \begin{tabular}{|l|} 
5. Objaśniania, na \\
czym polegają grzechy \\
popełniane przez \\
małżonków (aborcja, \\
antykoncepcja, \\
zapłodnienie in vitro)
\end{tabular} & 4,50 & 0,707 & 4,06 & 0,899 & 4,52 & 0,829 & 4,43 & 0,945 & 0,46 & 4,689 \\
\hline $\begin{array}{l}\text { 6. Prowadzenia spotkań } \\
\text { formacyjnych dla rodziców } \\
\text { w ramach przygotowania } \\
\text { do I Komunii św. } \\
\text { i sakramentu bierzmowania } \\
\end{array}$ & 4,30 & 0,823 & 4,00 & 0,935 & 4,21 & 0,774 & 4,22 & 0,600 & 0,30 & 0,981 \\
\hline $\begin{array}{l}\text { 7. Wspierania małżonków } \\
\text { przeżywających problem } \\
\text { niepłodności }\end{array}$ & 4,40 & 0,966 & 3,82 & 1,286 & 4,07 & 1,033 & 3,87 & 0,920 & 0,58 & 3,182 \\
\hline $\begin{array}{l}\text { 8. Organizowania formacji } \\
\text { rodziców wspierającej ich } \\
\text { w wychowaniu dzieci }\end{array}$ & 3,20 & 0,422 & 3,47 & 1,281 & 3,86 & 1,060 & 4,00 & 0,905 & $\mathbf{0 , 8 0}$ & 7,352 \\
\hline $\begin{array}{l}\text { 9. Przekazywania } \\
\text { nauczania moralnego } \\
\text { Kościoła dotyczącego } \\
\text { odpowiedzialnego } \\
\text { rodzicielstwa } \\
\end{array}$ & 4,50 & 0,527 & 4,12 & 0,928 & 4,31 & 1,004 & 4,26 & 0,752 & 0,38 & 1,457 \\
\hline $\begin{array}{l}\text { 10. Zachęcania małżonków } \\
\text { do poznawania i kierowania } \\
\text { się naturalnymi rytmami } \\
\text { płodności oraz do } \\
\text { korzystania } \\
\text { z NaProTECHNOLOGY } \\
\end{array}$ & 4,50 & 0,850 & 3,82 & 1,468 & 4,03 & 1,085 & 3,96 & 0,976 & 0,68 & 2,677 \\
\hline $\begin{array}{l}\text { 11. Modlitwy w intencji } \\
\text { małżonków, aby } \\
\text { wesprzeć ich w ich misji } \\
\text { prokreacyjno- } \\
\text {-wychowawczej }\end{array}$ & 4,40 & 0,843 & 4,24 & 1,033 & 4,66 & 0,670 & 4,57 & 0,662 & 0,42 & 3,246 \\
\hline $\begin{array}{l}\text { 12. Prowadzenia rozmów } \\
\text { z rodzicami, dotyczące } \\
\text { wychowania dzieci }\end{array}$ & 3,90 & 0,994 & 4,12 & 0,928 & 4,21 & 0,726 & 4,43 & 0,728 & 0,53 & 3,110 \\
\hline
\end{tabular}

Oznaczenia: $M$ - średnia, $S D$ - odchylenie standardowe; $d M$ - różnice między średnimi, $H$ - wynik testu Kruskala-Wallisa, $p$ - poziom istotności. Pogrubionym pismem oznaczono różnice istotne statystycznie. 
Wyniki zaprezentowane w tabeli 5, odnoszącej się do odbycia przez respondentów dodatkowej formacji pastoralnej, wskazują, że tylko w jednym wypadku występuje istotna statycznie różnica między porównywanymi grupami duszpasterzy. Duchowni, którzy odbyli dodatkową formację pastoralną $(M=4,35 \pm 0,69)$, czują się bardziej kompetentni do prowadzenia spotkań formacyjnych dla rodziców w ramach przygotowania do Pierwszej Komunii Świętej i sakramentu bierzmowania niż ci, którzy nie odbyli żadnej dodatkowej formacji ( $M=3,9 \pm 0,81 ; p=0,036$; różnica średnich $-0,38$ punktu).

Tabela 5. Poczucie gotowości do towarzyszenia małżonkom w odpowiedzialnym rodzicielstwie

a odbycie dodatkowej formacji przez respondentów

\begin{tabular}{|c|c|c|c|c|c|c|}
\hline \multirow{3}{*}{ Odczuwam gotowość } & \multicolumn{4}{|c|}{ Dodatkowa formacja } & \multirow{3}{*}{$d M$} & \multirow{3}{*}{ Z } \\
\hline & \multicolumn{2}{|c|}{ Nie } & \multicolumn{2}{|c|}{ Tak } & & \\
\hline & $M$ & $S D$ & $M$ & $S D$ & & \\
\hline $\begin{array}{l}\text { 1. Przepowiadania (w formie kazań i katechez) na temat etyki } \\
\text { małżeńskiej i odpowiedzialnego rodzicielstwa }\end{array}$ & 3,97 & 0,81 & 3,93 & 1,22 & 0,04 & $-0,529$ \\
\hline $\begin{array}{l}\text { 2. Przepowiadania o świętości i nienaruszalności ludzkiego } \\
\text { życia }\end{array}$ & 4,67 & 0,59 & 4,77 & 0,48 & $-0,10$ & $-0,747$ \\
\hline $\begin{array}{l}\text { 3. Ukazywania małżonkom ich powołania jako służby życiu } \\
\text { powierzonej przez Boga }\end{array}$ & 4,36 & 0,72 & 4,58 & 0,63 & $-0,22$ & $-1,425$ \\
\hline $\begin{array}{l}\text { 4. Pogłębiania moich kompetencji, aby lepiej pomagać } \\
\text { małżonkom w ich misji odpowiedzialnej prokreacji }\end{array}$ & 3,97 & 1,08 & 4,07 & 0,86 & $-0,10$ & $-0,167$ \\
\hline $\begin{array}{l}\text { 5. Objaśniania, na czym polegają grzechy popełniane przez } \\
\text { małżonków (aborcja, antykoncepcja, zapłodnienie in vitro) }\end{array}$ & 4,36 & 0,90 & 4,42 & 0,85 & $-0,06$ & $-0,304$ \\
\hline $\begin{array}{l}\text { 6. Prowadzenia spotkań formacyjnych dla rodziców w ramach } \\
\text { przygotowania do I Komunii św. i sakramentu bierzmowania }\end{array}$ & 3,97 & $\mathbf{0 , 8 1}$ & 4,35 & 0,69 & $-0,38$ & $-2,096$ \\
\hline $\begin{array}{l}\text { 7. Wspierania małżonków przeżywających problem } \\
\text { niepłodności }\end{array}$ & 3,83 & 1,11 & 4,14 & 0,99 & $-0,31$ & $-1,331$ \\
\hline $\begin{array}{l}\text { 8. Organizowania formacji rodziców wspierającej ich } \\
\text { w wychowaniu dzieci }\end{array}$ & 3,67 & 1,07 & 3,79 & 1,01 & $-0,12$ & $-0,408$ \\
\hline $\begin{array}{l}\text { 9. Przekazywania nauczania moralnego Kościoła dotyczącego } \\
\text { odpowiedzialnego rodzicielstwa }\end{array}$ & 4,36 & 0,83 & 4,21 & 0,89 & 0,15 & 0,795 \\
\hline $\begin{array}{l}\text { 10. Zachęcania małżonków do poznawania i kierowania się } \\
\text { naturalnymi rytmami płodności } \\
\text { oraz do korzystania z NaProTECHNOLOGY }\end{array}$ & 3,97 & 1,18 & 4,07 & 1,08 & $-0,10$ & $-0,345$ \\
\hline $\begin{array}{l}\text { 11. Modlitwy w intencji małżonków, aby wesprzeć ich w ich } \\
\text { misji prokreacyjno-wychowawczej }\end{array}$ & 4,53 & 0,88 & 4,49 & 0,70 & 0,04 & 0,781 \\
\hline $\begin{array}{l}\text { 12. Prowadzenia rozmów z rodzicami dotyczących } \\
\text { wychowania dzieci }\end{array}$ & 4,19 & 0,86 & 4,23 & 0,78 & $-0,04$ & $-0,032$ \\
\hline
\end{tabular}

Oznaczenia: $M$ - średnia, $S D$ - odchylenie standardowe; $d M$ - różnice między średnimi, $Z$ - Wynik testu Manna-Whitneya, $p$ - poziom istotności. Pogrubionym pismem oznaczono różnice istotne statystycznie.

\section{WNIOSKI PASTORALNE}

Z przeprowadzonych badań wynika, że ponad trzy czwarte badanych prezbiterów deklaruje gotowość towarzyszenia małżonkom w odpowiedzialnym rodzicielstwie poprzez przepowiadanie o świętości i nienaruszalności ludzkiego życia. Ponad połowa odczuwa gotowość podjęcia wsparcia modlitewnego małżonków w ich misji 
prokreacyjno-wychowawczej, objaśniania kwestii dotyczących grzechów w życiu małżeńskim, ukazywania służby życiu jako powołania małżonków powierzonego im przez Boga oraz przekazywania nauczania moralnego Kościoła dotyczącego odpowiedzialnego rodzicielstwa. Niewielki odsetek duszpasterzy $(3,8 \%)$ daje wyraz poczuciu braku gotowości do towarzyszenia małżonkom w odpowiedzialnym rodzicielstwie.

Zebrane wyniki wskazują, że badani prezbiterzy czują się gotowi do towarzyszenia małżonkom w odpowiedzialnym rodzicielstwie. Duszpasterze w swojej opinii są zmotywowani do tej posługi, mają poczucie kompetencji i posiadania właściwego przygotowania. Wykorzystane zmienne niezależne nie wykazują zasadniczo istotnych różnic wśród duszpasterzy w badanym obszarze. Z zaprezentowanych wyników można wysnuć jedynie wniosek, że starsi wiekiem prezbiterzy czują się lepiej przygotowani do duszpasterskiego wspierania małżonków w odpowiedzialnym rodzicielstwie, a zarazem wykazują motywację do poszerzania swych kompetencji w tym zakresie. Wydaje się, że wynika to ze zdobytego przez nich większego doświadczenia w posługiwaniu duszpasterskim. Doświadczenie to zdaje się równocześnie owocować pragnieniem podejmowania własnej formacji w obliczu współczesnych wyzwań dotyczących realizacji odpowiedzialnego rodzicielstwa przez małżonków.

Z perspektywy pastoralnej warto zwrócić szczególną uwagę na deklarowane przez badanych prezbiterów zapotrzebowanie na formację stałą duszpasterzy w zakresie duszpasterstwa rodzin. Należy pamiętać, że: „zadaniem formacji nie jest wykształcenie u osób duchownych, pracujących w duszpasterstwie rodzin, zupełnie nowych kompetencji, lecz stymulacja rozwoju już posiadanej wrażliwości, wiedzy i umiejętności"25. Wydaje się to istotne zwłaszcza dla duszpasterzy, którzy niewyraźnie potwierdzali gotowość do wspierania małżonków. Formacja ta mogłaby wspierać motywację i rozwój kompetencji duszpasterzy w omawianym zakresie. Duszpasterstwo rodzin, mające priorytetowe znaczenie w ewangelizacyjnej działalności Kościoła, wymaga skoncentrowania formacji duszpasterzy na przygotowaniu do pracy z małżonkami ${ }^{26}$. Przygotowanie seminaryjne oraz stała formacja prezbiterów powinny wychodzić naprzeciw zapotrzebowaniu wielu małżonków związane$\mathrm{mu} \mathrm{z}$ towarzyszeniem duchowym ${ }^{27}$.

${ }^{25}$ Jerzy SzymoŁon, „Formacja osób pracujących w duszpasterstwie rodzin”, w Duszpasterstwo rodzin. Refleksja naukowa i działalność pastoralna, red. Ryszard Kamiński, Grzegorz Pyźlak i Jacek Goleń (Lublin: Wydawnictwo KUL, 2013), 772.

${ }^{26}$ M. Polak, Ongoing Formation in Family Ministry for Priest, w: Catholic Family Ministry. The Scientific Reflection and the Practical Ministry of the Church, red. Jacek Golen, Ryszard Kamiński i Grzegorz Pyźlak, Lublin: Wydawnictwo KUL 2018, s. 642.

${ }^{27}$ Kongregacja Wychowania Katolickiego, Wskazania na temat formacji seminarzystów odnośnie problemów związanych z malżeństwem i rodzina (19.03.1995), 8, 64; por. J. Goleń, Formation 
Obiektywizacji obrazu duszpasterskiego towarzyszenia małżonkom w badanym obszarze przysłużyłyby się nowe badania, poszerzone o inne zmienne niezależne, które mogłyby przynieść szersze spojrzenie na interesujące nas pole działalności Kościoła. Refleksja teologicznopastoralna nad towarzyszeniem małżonkom w odpowiedzialnym rodzicielstwie nie może ograniczać się do badania duszpasterzy. W podejmowany namysł z pewnością wiele wniosłyby badania małżonków jako odbiorców posługi duszpasterskiej.

\section{BIBLIOGRAFIA}

FIDALGO, Antonio Gerardo. „Rzeczywistość miłości jako fundament małżeństwa i rodziny”. W Amoris laetitia jako ewangelia miłości i droga do przebycia, red. Giovanni del Missier, Antonio Gerardo Fidalgo. Kraków: Wydawnictow Homo Dei, 2019.

FrancisZeK. Adhortacja apostolska „Amoris laetitia” (19.03.2016), Wrocław: Wydawnictwo Wrocławskiej Księgarni Archidiecezjalnej, 2016.

GoleŃ, Jacek. „Duszpasterstwo rodzin wsparciem rodziców w wychowaniu”. Roczniki Teologiczne 66, z. 6 (2019): 177-92.

Goleń, Jacek. „Formation in Family Ministry for Seminarians”. W Catholic Family Ministry. The Scientific Reflection and the Practical Ministry of the Church, red. Jacek Goleń, Ryszard Kamiński i Grzegorz Pyźlak, 631-641. Lublin: Wydawnictwo KUL 2018.

Goleń Jacek. „Parish Family Counseling Centers”. W Catholic Family Ministry. The Scientific Reflection and the Practical Ministry of the Church, red. Jacek Goleń, Ryszard Kamiński i Grzegorz Pyźlak, 337-51. Lublin: Wydawnictwo KUL, 2018.

GoLEŃ, Jacek. „Poradnictwo małżeńsko-rodzinne”. W Duszpasterstwo rodzin, Refleksja naukowa i działalność pastoralna, red. Ryszard Kamiński, Grzegorz Pyźlak i Jacek Goleń, 378-93. Lublin: Wydawnictwo KUL 2013.

Goleń, Jacek. „Spiritual Direction for Spouses”. W Catholic Family Ministry. The Scientific Reflection and the Practical Ministry of the Church, red. Jacek Goleń, Ryszard Kamiński i Grzegorz Pyźlak, 287-299. Lublin: Wydawnictwo KUL 2018.

GoleŃ, Jacek. „The Challenges of Accompanying Families in Light of the Apostolic Exhortation Amoris Laetitia". Rocznik Teologii Katolickiej 17, nr 1 (2018): 103-7.

GoLEŃ, Jacek. „Wspieranie rodzin w wychowaniu seksualnym”. W Towarzyszyć matżeństwu i rodzinie. Inspiracje adhortacji apostolskiej Amoris laetitia dla duszpasterstwa rodzin, red. Jacek Goleń, 343-60. Lublin: Wydawnictwo KUL 2017.

Granados, José, Stephan Kampowski i Juan José PÉrez-Soba. Accompanying, Discerning, Integrating. A Handbook for the Pastoral Care of the Family According to Amoris Laetitia, Steubenville: Emmaus Road Publishing, 2015.

JAN PAWEe II. „Adhortacja apostolska «Familiaris consortio» (22.11.1981)”. W Adhortacje Ojca Świętego Jana Pawła II, t. I, 65-160. Kraków: Wydawnictwo św. Stanisława B.M., Wydawnictwo M, 1996.

in family ministry for seminarians, w Catholic Family Ministry. The Scientific Reflection and the Practical Ministry of the Church, red. Jacek Goleń, Ryszard Kamiński i Grzegorz Pyźlak, Lublin: Wydawnictwo KUL 2018, s. 636. 
JAN PAWEe II. Adhortacja apostolska „Pastores dabo vobis” (25.03.1992). Wrocław: Wydawnictwo Wrocławskiej Księgarni Archidiecezjalnej, 1995.

JAN PAwEŁ II. „Encyklika «Evangelium vitae» (25.03.1995)”. W Encykliki Ojca Świętego Jana Pawła II, t. II, 639-752. Kraków: Wydawnictwo św. Stanisława B.M., Wydawnictwo M, 1996.

JAN PAWEe II. „List do Rodzin «Gratissimam sane» (2.02.1994)”. W Posoborowe dokumenty Kościoła katolickiego o małżeństwie i rodzinie, t. II, 33-103. red. Kazimierz Lubowicki. Kraków: Wydawnictwo M, 1999.

JAN PAWE⿺ II. Medytacja o bezinteresownym darze (8.02.1994), 2-3, https://opoka.org.pl/biblioteka/W/ WP/jan_pawel_ii/inne/medytacja_08021994.html [dostęp: 30.01.2020].

Katechizm Kościoła katolickiego (11.10.1992). Poznań: Pallottinum, 1994.

Konferencja EpISKOPATU POLSKI. Dyrektorium duszpasterstwa rodzin (1.05.2003). Warszawa: Fundacja Vita Familiae, 2003.

KONGREGACJA WyCHOWANIA KATOLICKIEGO. Wskazania na temat formacji seminarzystów odnośnie do problemów zwiąanych z matżeństwem i rodzina (19.03.1995).

Kornas-Biela, Dorota. „Pedagogika prenatalna”. W Pedagogika. Podręcznik akademicki. Subdyscypliny i dziedziny wiedzy o edukacji, t. 4, 149-173. red. Bogdan Śliwerski, Gdańsk: Gdańskie Wydawnictwo Psychologiczne, 2010.

KUCHARČIK, Richard. „Odnowa przygotowania do małżeństwa w parafii”. W Duszpasterstwo rodzin w parafii, red. Jacek Goleń i Dariusz Lipiec, 195-206. Lublin: Wydawnictwo KUL, 2016.

PAweŁ VI. Encyklika „Humanae vitae” (25.07.1968). Wrocław: Wydawnictwo Wrocławskiej Księgarni Archidiecezjalnej, 1999.

Polak, Mieczysław. „Ongoing Formation in Family Ministry for Priest”. W Catholic Family Ministry. The Scientific Reflection and the Practical Ministry of the Church, red. Jacek Golen, Ryszard Kamiński i Grzegorz Pyźlak, 641-51. Lublin: Wydawnictwo, KUL 2018.

SkreCzKo, Adam. „Pedagogizacja rodziców”. W Duszpasterstwo rodzin. Refleksja naukowa i dziatalność pastoralna, red. Ryszard Kamiński, Grzegorz Pyźlak i Jacek Goleń, 456-472. Lublin: Wydawnictwo KUL, 2013.

SzymoŁon, Jerzy. „Formacja osób pracujących w duszpasterstwie rodzin”. W Duszpasterstwo rodzin, Refleksja naukowa i działalność pastoralna, red. Ryszard Kamiński, Grzegorz Pyźlak i Jacek Goleń, 771-779. Lublin: Wydawnictwo KUL 2013.

\section{DUSZPASTERSKIE TOWARZYSZENIE MAŁŻONKOM W ODPOWIEDZIALNYM RODZICIELSTWIE}

\section{Streszczenie}

Duszpasterskie towarzyszenie małżonkom w odpowiedzialnym rodzicielstwie należy do istotnych zadań tej zbawczej działalności Kościoła. Małżonkowie zaproszeni przez Boga do realizacji powołania rodzicielskiego oczekują na wsparcie płynące ze strony duszpasterzy. Wsparcie to jest realizowane przez kapłanów poprzez przepowiadanie słowa Bożego, parafialne poradnictwo rodzinne, posługę kierownictwa duchowego i wsparcia modlitewnego czy też w procesie pedagogizacji. Przeprowadzone wśród prezbiterów badania dowiodły, że wysoki odsetek księży deklaruje gotowość duszpasterskiego towarzyszenia małżonkom w dziele odpowiedzialnego rodzicielstwa. Częściej tak uważają zwłaszcza kapłani starsi, powyżej 36. roku życia, mający większe doświadczenie posługiwania dla małżeństw. Wyzwanie wsparcia duszpasterskiego małżonków w odpowiedzialnym rodzicielstwie stanowią kapłani młodsi, do 35 roku życia.

Słowa kluczowe: towarzyszenie duszpasterskie; odpowiedzialne rodzicielstwo; duszpasterstwo małżeństw; badania kapłanów. 